\title{
Islam Nusantara: Solusi Menyikapi Problem Radikalisme Agama
}

\author{
Alif Jabal Kurdi \\ Universitas Islam Negeri Sunan Kalijaga Yogyakarta \\ alifjabalkurdi@gmail.com \\ Nur Azka Inayatussahara \\ Universitas Islam Negeri Sunan Kalijaga Yogyakarta \\ inayael84@gmail.com
}

\begin{abstract}
Islam coming to Indonesia is not coming to an empty land, but its people have built up on a strong tradition and culture. As an initiative step, the preachers used the dialectical approach of culture. Nusantara Islam is a religious expression that is in accordance with the local culture of the archipelago, because there is a dialectic between religious texts and local Nusantara culture and traditions. However, Nusantara Islam has been misunderstood by the notion of radicalism, this group does not accept acculturation of culture in religion. So that the negative view of the Nusantara Islam in it accommodates local cultural rituals. So this paper aims to discuss how the dialectics of culture and religion in the context of the spread of Islam as exemplified at the time of the Prophet and in the time of Walisongo. To support the course of this study researchers used a historical analysis approach. As a result of the analysis the researchers found that cultural and religious dialectics had taken place at the time of the Prophet. in the face of the traditions of the people of Mecca, the Prophet did not reject and erase all their long-standing practices. so that what was done by Indonesian preachers is not contradictory in Islam. Thus, this paper is expected to be able to answer the negative responses of puritans who want to purge Islam from all forms of cultural acculturation in it and be able to affirm Nusantara Islam as a characteristic of Indonesian Islam free of radicalism and respect for plurarity.
\end{abstract}


Alif Jabal Kurdi

Abstrak: Islam datang ke Indonesia bukanlah datang ketanah yang kosong, melainkan masyarakatnya telah terbangun diatas tradisi dan kebudayaan yang kokoh. Sebagai langkah inisiatif, para pendakwah menggunakan pendekatan dialektika kebudayaan. Islam Nusantara merupakan ekspresi keberagamaan yang sesuai dengan budaya lokal Nusantara, karena di dalamnya terdapat dialektika antara teks keagamaan dengan budaya dan tradisi lokal Nusantara. Akan tetapi, Islam Nusantara telah disalahpahami oleh paham radikalisme, kelompok ini tidak menerima akulturasi budaya dalam agama. Sehingga memandang negatif Islam Nusantara yang di dalamnya mengakomodasi ritual budaya lokal. Maka tulisan ini bertujuan membahas bagaimana dialektika budaya dan agama dalam rangka penyebaran Islam sebagaimana dicontohkan pada masa Rasulullah dan di masa walisongo. Untuk menunjang jalannya penelitian ini peneliti menggunakan pendekatan analisis historis. Sebagai hasil analisis peneliti menemukan bahwa dialektika budaya dan agama telah terjadi pada masa Rasulullah. dalam menghadapi tradisi penduduk Makkah, Nabi tidak menolak dan menghapus keseluruhan praktik yang sudah sejak lama dilakukan mereka. sehingga apa yang dilakukan oleh pendakwah Indonesia tidaklah bertentangan dalam Islam. Dengan demikian diharapkan tulisan ini mampu menjawab tanggapan negatif kaum puritan yang ingin membersihkan Islam dari segala bentuk akulturasi budaya yang ada di dalamnya serta mampu meneguhkan Islam Nusantara sebagai ciri khas Islam Indonesia yang bebas dari radikalisme dan menghargai pluraritas.

Kata Kunci: Budaya, Islam Nusantara, Radikalisme

\section{A. Pendahuluan}

Kelompok radikal atau secara khusus kelompok Muslim yang berpemahaman radikal tidak menghendaki adanya praktik dan pelestarian budaya. Hal ini seperti yang dikatakan oleh Haidar Bagir, bahwa kekhawatiran akan eksklusivisme legal-tekstual dan paham Islam transnasional yang cenderung memusuhi budaya banyak mewarnai wacana keagamaan dewasa ini. Talibanisme, misalnya, menghancurkan patung Buddha di Bamiyan Afghanistan. ISIS (Negara Islam di Irak dan Suriah), di sisi lain, merepresentasikan sebuah kelompok yang lebih radikal, puritan, dan brutal. Dalam gerakannya, kelompok ini bukan hanya memerangi kelompok yang tidak sejalan dengannya, melainkan juga begitu memusuhi budaya lokal, baik berupa artefak budaya, maupun pemikiran dan tradisi-tradisinya. 
Meski demikian, lebih lanjut menurut Haidar Bagir banyak isyarat yang menampilkan bahwa tawaran pemikiran puritan ala ISIS ini mendapat penerimaan beberapa kalangan umat Muslim, termasuk Muslim Indonesia. ${ }^{1}$ Beberapa tradisi budaya masyarakat Indonesia yang telah melekat sejak lama belakangan mulai terdengar dianggap sebagai praktik bid'ah (untuk tidak mengatakan dibenci dan dimusuhi), seperti selametan, tujuh harian, dan nyadran. Jika dibandingkan dengan ISIS yang menghancurkan artefak budaya, tindakan tersebut lebih bersifat memusuhi secara "ideal". Namun, baik apa yang dilakukan oleh ISIS atau yang dilakukan oleh sebagian kelompok Muslim radikal di Indonesia, keduanya merupakan suatu hal yang tidak dapat dibenarkan. Budaya memang bukanlah bagian dari agama, namun eksistensinya tidak dapat dinafikan. Bahkan, Islam sekalipun pada masa awal kemunculannya mengakomodasi eksistensi budaya Arab yang ada kala itu dan menjadikannya sebagai media. Meminjam pernyataan Ali Sodiqin, "Islam bukanlah produk budaya, namun dapat mewarnai berbagai aspek kebudayaan. Dalam implementasi ajarannya, dibutuhkan media untuk mentransformasikan nilai-nilai universalnya ke dalam praksis kehidupan". 2

Rasulullah berperan dalam reformasi budaya Arab manakala ajaran Islam tersebar melalui pewahyuan al-Qur'an. Sebagai sebuah wahyu yang ditransmisikan secara lisan, al- Qur'an pun dalam prosesnya mempertimbangkan dan berinteraksi dengan konteks budaya yang sedang terjadi di tempat diturunkannya. Sebagai contoh, penduduk Makkah pada saat itu merupakan sebuah komunitas yang senang dengan lantunan-lantunan syair. Maka, ayat- ayat al-Qur'an yang diterima Nabi di daerah tersebut mengikuti pola syair penduduk setempat yang puitis dan singkat. Begitu pula dalam menghadapi tradisi penduduk Makkah. Nabi tidak menolak dan menghapus keseluruhan praktik yang sudah sejak lama dilakukan mereka. Beberapa tradisi diterima Nabi dengan disertai perbaikan, beberapa yang lain tetap ada namun diubah orientasinya, dan beberapa lagi

${ }^{1}$ lihat Haidar Bagir, Islam Tuhan Islam Manusia Agama Dan Spiritualitas Di Zaman Kacau (Bandung: Mizan, 2007).

2 lihat pada Ali Sodiqin, "Sejarah Harmonisasi Islam Dan Kebudayaan Mazhabuna," Digilib Uin Suka. Ac.Id, 1, 7 (2013).

Analisis: Jurnal Studi Keislaman, Volume 19, No. 1, Juni 2019 
secara mutlak dihilangkan. ${ }^{3}$ Berdasarkan hal ini, dapat diketahui bahwa Islam tidak serta-merta menolak eksistensi budaya seperti yang selama ini diyakini oleh kelompok-kelompok radikal. Anggapan mereka bahwa budaya dan tradisi adalah bid'ah harus ditelaah kembali, karena jika ditelisik lebih jauh, dakwah Nabi yang bersifat ramah budaya tersebut dahulu diadaptasi oleh para penyebar Islam, yaitu ulama di Indonesia.

Ulama Nusantara, khususnya walisongo, menggunakan metode dakwah Nabi yang berdialektika dan terintegrasi dengan budaya disertai dengan adanya kontekstualisasi terhadap situasi, kondisi, adat, dan tradisi yang sejak lama telah dipraktikkan masyarakat Indonesia. Secara bijaksana, mereka berhasil memanfaatkan kearifan budaya lokal untuk dijadikan sarana dalam menyebarkan ajaran-ajaran Islam. Hal ini karena mereka menyadari bahwa budaya lokal adalah sesuatu yang sangat melekat dalam kehidupan sosial masyarakat, bahkan membentuk karakter mereka. Sehingga, berbaurnya nilai dan ajaran Islam ke dalam budaya lokal diharapkan mampu menjadi sarana yang efektif untuk mengambil hati masyarakat agar berkenan menerima ajaran-ajaran Islam. Salah satu bentuk kebudayaan lokal masyarakat Nusantara yang berhasil diislamisasi atau di-Islam-kan oleh para ulama adalah budaya nyanyian. Jika sebelumnya nyanyian-nyanyian sering ditujukan untuk memuja roh-roh halus, maka para ulama mengubahnya menjadi sarana untuk memuji Nabi Muhammad SAW, atau di tanah jawa khususnya lebih dikenal dengan istilah sholawatan.

Dakwah Islam yang dikembangkan oleh walisongo dan ulama Nusantara lainnya di era selanjutnya melahirkan sebuah gagasan baru yang dikenal dengan istilah Islam Nusantara. Sebagai sebuah pemikiran, Islam Nusantara memberikan tawaran gagasan keberagamaan Islam khas Indonesia berupa sintesis antara wahyu dan budaya yangmengandung nuansa kearifan lokal. Secara historis berkaitan dengan perannya dalam melawan paham radikalisme, gagasan ini dijadikan tema utama dalam Muktamar Nahdlatul Ulama ke-33 tahun 2015 di Jombang, Jawa Timur. Hal ini muncul sebagai respons atas merosotnya citra Islam di kancah internasional dengan

${ }^{3}$ lihat Ali Sodiqin, Antropologi Al-Qur'an: Model Dialektika Wahyu Dan Budaya (Yogyakarta: Ar-Ruzz Media, 2012). 
maraknya peristiwa kekerasan yang mengatasnamakan Islam. ${ }^{4}$ Oleh karena itu, berdasarkan hal tersebut, jika dikaitkan dengan keadaan bangsa Indonesia sekarang, sintesis awal penulis adalah bahwa Islam Nusantara dapat mereduksi dan menjadi wacana tandingan atas paham dan praktik radikalisme yang berkembang di Indonesia pada masa milenial seperti sekarang, dimana paham radikalisme dapat menyebar bahkan melalui gawai kecil sekalipun.

Secara akademik, para ahli telah banyak menuliskan gagasangagasan mereka mengenai wacana Islam Nusantara. Beberapa yang menjadi referensi tulisan ini adalah, pertama, karya Ahmad Baso, Islam Nusantara Ijtihad Jenius dan Ijma' Ulama Indonesia. Buku ini memaparkan bagaimana konstruksi gagasan Islam Nusantara dalam perspektif para ulama dan kalangan pesantren. Secara khusus, buku ini membincang hal-hal bahwa banyak yang harus dilakukan oleh para kiai dan santri untuk meneguhkan kembali Islam Nusantara. ${ }^{5}$ Kedua, karya Ali Sodiqin, Antropologi Al-Qur'an: Model Dialektika Wahyu dan Budaya. Secara antropologis, Sodiqin menuliskan gagasangagasannya tentang keterkaitan wahyu al-Qur'an dengan budaya, dengan sebuah tesis bahwa al-Qur'an relevan pada setiap zaman dan waktu. ${ }^{6}$ Beberapa sumber tersebut oleh penulis diolah dengan pendekatan analisis historis-antropologis dan metode kualitatif berbasis library research, sehingga pembahasan dalam tulisan ini berkaitan dengan dua perspektif tersebut. Penulis akan memfokuskan pada pembahasan bagaimana Islam berdialektika dengan budaya, dimulai dari Islam pada masa $\mathrm{Nabi}$, walisongo, hingga akhirnya tercipta gagasan Islam Nusantara; dan relevansinya terhadap permasalahan radikalisme Islam yang terjadi di Indonesia pada masa milenial seperti sekarang. Hemat penulis, beberapa upaya kritis yang diambil dari esensi Islam Nusantara harus dilakukan untuk mereduksi paham radikalisme di tengah arus zaman milenial, seperti penyebaran

${ }^{4}$ lihat Al-Qathan Manna', Mabahits Fi Ulum Al-Qur'an (Beirut: Dar alKutub al-Ilmiyah, 1973) lihat juga pada; Qomar Mujamil, "Islam Nusantara: Sebuah Alternatif Model Pemikiran, Pemahaman, Dan Pengamalan Islam”., vol. 2, 17 (El Harakah, 2015).

${ }^{5}$ Ahmad Baso, Islam Nusantara Ijtihad Jenius Dan Ijma' Ulama Indonesia (Tangerang Selatan: Pustaka Afid, 2015). Budaya.

${ }^{6}$ Ali Sodiqin, Antropologi Al-Qur'an: Model Dialektika Wahyu Dan 
Islam Nusantara yang ramah melalui media gawai, internet, dan media social.

\section{B. Radikalisme Islam di Indonesia}

Wacana radikalisme Islam telah sejak lama muncul di kancah internasional. ${ }^{7}$ yang kemudian pada era-milenial ini gencar merebak berkat media massa dan media sosial, seperti yang dikatakan oleh Hamdi Muluk bahwa paham ini begitu memanfaatkan media sosial. Meski tidak lahir dari dunia Islam, radikalisme dalam agama Islam diyakini sebagai produk ciptaan yang muncul pada abad ke-20, yang secara terstruktur dalam kaitannya dengan hegemoni Barat memunculkan adanya seruan untuk kembali kepada ajaran Islam yang murni sebagai solusi dari segala masalah. ${ }^{8}$ Gerakan ini cenderung menolak segala sesuatu yang dianggap tidak sesuai dengan pemahaman ideologis para penggagasnya, bahkan disertai dengan tindakan kekerasan. Meski demikian, mereka mengklaim bahwa perbuatan tersebut telah dilegitimasi oleh dalil-dalil agama. Hal ini mengakibatkan munculnya stigma bahwa Islam adalah agama kekerasan. Bahkan, di beberapa negara muncul kelompok-kelompok yang membenci Islam, atau yang dikenal dengan istilah islamophobia. Akibatnya, wajah Islam yang teduh sebagai agama yang mengajarkan perdamaian berubah menjadi agama yang mengancam perdamaian.

Dalam kamus besar Bahasa Indonesia, radikalisme diartikan dengan "paham atau aliran yang menginginkan perubahan atau pembaharuan sosial dan politik dengan cara kekerasan atau drastic. ${ }^{9}$ Jika dikaitkan dengan agama Islam, menurut Syeikh Yusuf alQardhawi radikalisme adalah fanatik kepada satu pendapat dan menegasikan pendapat lain, mengabaikan historisitas Islam, tidak dialogis, dan harfiah dalam memahami teks agama tanpa

${ }^{7}$ Bibit Suprapto, Ensiklopedi Ulama Nusantara (Bogor: Gelegar Media Indonesia, 2009); lihat juga Ummah Choirol Sun, "Akar Radikalisme Islam Di Indonesia," Humanika, no. 2 (2012), media.neliti.com; Umar Nasaruddin, Deradikalisasi Pemahaman Al-Qur'an Dan Hadis (Jakarta: Quanta, 2009).

${ }^{8}$ Anzar Abdullah, "Gerakan Radikalisme Dalam Islam: Perspektif Historis," Addin, 1, 10 (2016), www.researchgate.net.

${ }^{9}$ Muhammad Hasan Tholhah, Islam Dan Radikalisme Agama diakses 20 Maret 2018. (lp3.um.ac.id, 2013). 
mempertimbangkan tujuan esensial syariat (maqasid al-syari'at). ${ }^{10}$ Istilah radikalisme Islam ini sering dihubungkan dengan fundamentalisme dalam Islam. Dalam tradisi Barat, fundamentalisme Islam sering ditukar dengan istilah ekstrimisme Islam, Islam radikal, integrisme, revivalisme, atau islamisme. ${ }^{11}$

Ciri-ciri Islam radikal atau Islam revivalis, menurut John L. Esposito dalam bukunya "Islam and Secularism in The Middle East" adalah, pertama, kebencian terhadap Barat. Barat selalu diposisikan sebagai musuh, dimana tidak ada keinginan untuk melakukan dialog dengan mereka. Kedua, membentuk pemerintahan Islam sebagai kewajiban syariat Islam yang mutlak. Jika dikaitkan dengan keadaan di Indonesia, berdasarkan karakteristik ini kelompok radikalis enggan menjadikan Pancasila sebagai ideologi. Mereka berdalih bahwa Pancasila adalah ideologi sekuler yang memisahkan antara negara dan agama, sehingga tidak boleh diberlakukan. Ketiga, pemerintah yang tidak berdasarkan syariat dianggap tidak sah dan kafir, meski dibentuk oleh umat Muslim. Ini merupakan salah satu alasan mengapa kaum radikalis benar-benar memaksakan agar khilafah Islamiyah diterapkan di bumi nusantara. Keempat, wajib oposisi terhadap pemerintah yang tidak berdasar Islam. Dalam perjuangan mereka mewujudkan khilafah Islamiyah, mereka menggunakan berbagai langkah. Salah satunya adalah bersikap oposisi terhadap pemerintah, sehingga mereka bebas untuk mengkritik setiap tindakan pemerintah dan menunggu waktu yang tepat untuk menjatuhkan pemerintahan. Kelima, wajib jihad atau memerangi pemerintah yang tidak berdasar Islam. Ini adalah puncak dari tindakan kaum radikalis, menggunakan kata "jihad" sebagai legitimasi dari segala tindakan keras dan merusak mereka, yang kemudian menyebabkan munculnya aksi terorisme. ${ }^{12}$ Sebagai contoh, tindakan Amrozi, Imam Samudra dkk, yang melakukan pengeboman di Bali, diklaim mereka sebagai bagian dari jihad membela agama.

Selain yang telah dikemukakan Esposito, menurut M. I. Rahmat, seperti yang dikutip oleh Nurjannah, paham radikalisme Islam memiliki ciri radikal, berkarakter keras dan tegas, dan tanpa kompromi

10 Irwan Masduki, Berislam Secara Toleran Teologi Kerukunan Umat Beragama (Bandung: Mizan Pustaka, 2011).

${ }^{11}$ Abdullah, "Gerakan Radikalisme Dalam Islam: Perspektif Historis."

${ }^{12}$ lihat John L Esposito, Islam And Secularism In The Middle East (London: C. Hurst and Co, 2002). 
dalam mencapai suatu hal yang berkaitan dengan kelompok Muslim tertentu atau bahkan dengan pandangan dunia (world view) tertentu dalam agama Islam. Lebih lanjut menurutnya, kesan bahwa suatu kelompok berpaham 'keras' terlihat dari nama yang dipakainya, seperti Jundullah (tentara Allah), Laskar Jihad, Hizbullah (partai Allah), atau Front Pembela Islam (FPI) (Nurjannah, 2013: 180). Berdasarkan halhal tersebut, dapat terlihat bagaimana wajah Islam radikal yang begitu phobia dengan Barat. Salah satu indikasinya adalah tidak adanya kemauan untuk berinteraksi dengan Barat dalam bentuk dialog apapun. Pemahaman mereka terhadap teks-teks agama yang cenderung tekstualis, skriptualis, bahkan sangat Arab-sentris menjadikan citra pemikiran kelompok ini terkesan ekstrim. Dalam konteks kebernegaraan Indonesia, mereka berpendapat bahwa Pancasila adalah hasil murni ijtihad manusia, sehingga tidak dapat dijadikan dasar ideologi atau pedoman berkehidupan atau sederhananya dianggap sebagai sebuah produk ideologi sekuler. Padahal, nilai-nilai aksiologis yang terkandung dalam Pancasila dan UUD 1945 merupakan hasil saringan nilai-nilai relevan al-Qur'an dan Hadis yang dirumuskan oleh para ulama di Indonesia dengan mempertimbangkan maqashid alsyari'ah di dalamnya.

\section{Dialektika Budaya dan Agama: Aspek Moderasi Islam}

1. Rasulullah dan Budaya Arab: Sebuah Analisis HistorisAntropologis

Lahir dan besar di tengah-tengah komunitas Arab menyebabkan Nabi Muhammad begitu mengenal dan memahami karakteristik kebudayaan masyarakat yang berkembang dan berlaku kala itu. Tatkala datang kepadanya risalah Tuhan, ia harus menyusun strategi guna melancarkan misinya sebagai pembawa risalah. Salah satunya ialah dengan memperhatikan pola kehidupan masyarakat sehingga mampu menemukan sarana atau media yang tepat guna mentransmisikan nilai-nilai substansial dalam setiap risalah yang dibawanya. ${ }^{13}$

Dalam upayanya mentransmisikan nilai-nilai ajaran Islam yang terkandung dalam risalah Tuhan (Al-Qur'an) yang dipikulnya, Nabi

${ }^{13}$ lihat Ali Sodiqin, Antropologi Al-Qur'an: Model Dialektika Wahyu Dan Budaya. 
juga dituntut mampu mereformasi kebudayaan masyarakat Arab. Adanya konsep makkiy-madaniy dalam kajian keilmuan al- Qur'an (ulum al-Qur'an) menjadi sebuah indikasi bahwa al-Qur'an pun mengisyaratkan Muhammad untuk melakukan reformasi budaya masyarakat. $^{14}$

Bentuk reformasi yang diinginkan al-Qur'an dapat dilihat dari adanya dua fase di atas, dimana al-Qur'an ingin menjalin interaksi dengan situasi dan kondisi turunnya (konteks). Namun, menjadi catatan penting bahwa tidak semua nilai-nilai ajaran Islam dalam al-Qur'an dapat diinteraksikan dengan situasi dan kondisi budaya tertentu.

Islam sebagai ajaran agama, jika merujuk pada pemikiran Amin Abdullah, terbagi ke dalam dua dimensi yakni dimensi normatif dan dimensi historis. Dalam dimensi normatif, tedapat realitas transendental atau bisa juga disebut sebagai realitas ketuhanan yang bersifat baku (absolute) dan universal, sehingga tidak bisa diikat pada ruang dan waktu tertentu. Sedangkan yang dimaksud dengan dimensi historis adalah realitas kemanusiaan dimana agama tidak bisa dilepaskan dari sisi humanis manusia yang terikat pada konteks ruang dan waktu, sebab agama lahir dari konteks kehidupan pemeluknya. Sehingga, antara dimensi normatif dengan dimensi historis, keduanya tidak dapat dipisahkan. ${ }^{15}$

Apabila teori itu diterapkan dalam upaya menganalisis kandungan nilai dalam al- Qur'an, tentunya secara logis hasil yang didapatkan tidak akan bertentangan karena sumber induk ajaran Islam sendiri adalah al-Qur'an. Hal ini dibuktikan oleh Ali Sodiqin yang merumuskan bahwa dalam al-Qur'an terdapat ajaran yang bersifat fundamental dan instrumental. ${ }^{16}$

Ajaran fundamental ialah ajaran-ajaran pokok yang merupakan nilai universal dari ajaran al-Qur'an yang harus diberlakukan kapanpun dan di manapun. Sehingga, nilai universal ini sifatnya abadi dan tidak dapat dipengaruhi oleh ataupun tunduk dengan adat istiadat maupun sistem sosial-kebudayaan yang berlaku di masyarakat tertentu. Adapun

${ }^{14}$ Manna', Mabahits Fi Ulum Al-Qur'an.

15 lihat Yusuf and dkk, Islam Dan Budaya Lokal (Yogyakarta: Pokja Akademik UIN Sunan Kalijaga, 2005). Budaya.

16 Ali Sodiqin, Antropologi Al-Qur'an: Model Dialektika Wahyu Dan 
yang dimaksud dengan ajaran instrumental adalah antonim terminologis dari ajaran fundamental. Jadi, ajaran instrumental adalah ajaran-ajaran yang memiliki keterkaitan erat atau bahkan dibangun dengan menggunakan simbol-simbol adat istiadat serta konstruk sosialkebudayaan masyarakat yang berlaku saat itu. Simbol-simbol budaya ini dapat dipahami sebagai instrumen dalam mengimplementasikan ajaran-ajaran fundamental. ${ }^{17}$

Argumentasi di atas menguatkan teori sebelumnya bahwa tidak ada dikotomi antara ajaran normatif dengan ajaran historis. Namun sebaliknya, keduanya ibarat dua mata uang dimana ajaran normatif atau nilai-nilai universal dalam agama tidak akan tersampaikan jika tidak ada ajaran historis yang mengadopsi simbol-simbol kebudayaan (enkulturasi), sehingga mampu menjadi media yang menjembatani transmisi nilai-nilai universal agama kepada manusia. Ini membuktikan bahwa al-Qur'an tidak selamanya bersikap destruktif tetapi bahkan bersikap akomodatif dan apresiatif.

Melihat respons al-Qur'an terhadap pranata-pranata sosial yang ada pada konteks kala itu dapat menjadi sebuah sarana dalam menganalisis model dialektika yang terjadi antara Nabi dan budaya masyarakat Arab. Dalam teorinya, Ali Sodiqin merumuskan tiga model respons al-Qur'an terhadap budaya Arab, yaitu tahmil, taghyir, dan tahrim-yang akan dijelaskan setelah ini. ${ }^{18}$ Adapun dasar diferensiasi tersebut ialah konsep monoteisme (tauhid) yang dikandung dalam alQur'an, yang kemudian menjadi world view Islam dan mendasari semua bentuk ketetapan baik masalah ibadah maupun muamalah. Perlu dipahami bahwa konsep tauhid yang secara vertikal dimaknai sebagai konsep mengesakan Tuhan memiliki implikasi secara horizontal yaitu dengan munculnya konsep egalitarian. Dari sini maka hadir sebuah konsep tauhid sosial yang menginternalisasi konsep kesetararan sosial (social equity) dan humanisasi tradisi.

Tahmil secara bahasa berarti mengadopsi. Maksudnya di sini adalah sikap apresiatif terhadap sebuah tradisi budaya yang kemudian diterima dan diadopsi serta disempurnakan. Adapun contohnya semisal ritual $s a$ ' $i$ pada ibadah haji. Sa'i adalah ritual yang sebelumnya biasa

\footnotetext{
${ }^{17}$ Ibid.
}

${ }^{18}$ Ibid. 
dikerjakan oleh orang-orang Jahiliyah. Dahulu, di puncak bukit Shofa terdapat sebuah

berhala yang bernama Usaf, sedangkan di puncak bukit Marwah terdapat sebuah berhala juga yang bernama Nailah. Mereka mengelilingi kedua bukit tersebut sembari mengusap kedua berhala. Maka kedatangan Islam tidak bertujuan untuk menghapus tradisi tersebut, tetapi mengapresiasi dan menjadikannya sebagai salah satu syiar Islam, bukan syiar Jahiliyyah (Nawawi, 1997). Taghyir secara bahasa berarti mengubah. Dalam hal ini yang dimaksud dengan taghyir adalah sikap al-Qur'an yang menerima tradisi Arab, tetapi memodifikasinya sedemikian rupa sehingga karakter dasarnya berubah. Al-Qur'an tetap menggunakan simbol- simbol budaya yang ada namun keberlakuannya disesuaikan dengan world view ajaran Islam, yaitu tauhid, sehingga karakter aslinya berubah. Dalam hal ini contohnya semisal pembagian warisan. Dalam tradisi Arab Jahiliyah, wanita tidak diperhitungkan eksistensinya dan cenderung hanya dianggap sebagai budak hawa nafsu pria pada zaman itu. Tentulah ia tidak akan mendapatkan apa yang disebut dengan harta warisan, karena pada waktu itu model pembagian warisan masih bersifat patrilinieal. AlQur'an pun tetap mengadopsi model patrilinieal tersebut, namun alQur'an juga merekonstruksi aturan yang ada di dalamnya dengan memberikan bagian bagi perempuan. Dalam hal ini, dapat dilihat bahwa Islam menginginkan adanya kesamaan derajat (keseimbangan) antara perempuan dan laki-laki. ${ }^{19}$

Tahrim secara bahasa berarti melarang. Adapun pengertiannya di sini dapat dipahami sebagai sikap penolakan terhadap suatu tradisi masyarakat. Pelarangan ini didasari oleh turunnya ayat-ayat al-Qur'an yang memang menginstruksikan adanya dekonstruksi atas budaya yang dianggap tidak memiliki maslahat. Adapun budaya yang dilarang praktiknya setelah datangnya Islam di antaranya adalah budaya minum khamr. Namun, pelarangan ini tidak terjadi dalam sekali kesempatan melainkan secara bertahap. Hal ini juga membuktikan bahwa Tuhan mempertimbangkan pola kebudayaan manusia yang memerlukan waktu untuk merombaknya, karena tradisi meminum khamr

${ }^{19}$ Ibid. 
sebelumnya memang sebuah budaya yang mengakar pada masyarakat Arab waktu itu. ${ }^{20}$

Deskripsi di atas memperlihatkan bahwasanya Islam sejak awal turunnya telah mengalami interaksi dan dialektika dengan kebudayaan masyarakat. Tentunya ini menyebabkan pembentukan ajaran Islam tidak bisa dilepaskan dari budaya lokal. Sebab tradisitradisi tersebut merupakan media yang dimanfaatkan oleh al-Qur'an sebagai sarana menyampaikan pesan-pesan universal dalam ajaran Islam; mengubah paradigma dari politeisme ke monoteisme, dari komunitas 'ashabiyyah menjadi ummah, dan dari sistem sosial yang berkelas ke sistem yang berlandaskan kesetaraan sosial (social equity). Model dialektika inilah yang membentuk sebuah kebudayaan baru yang Islami namun tetap memiliki nilai khas budaya lokal pembentuknya. Model harmonisasi inilah yang semestinya dikembangkan pada masa pasca pewahyuan al-Qur'an sehingga mampu melahirkan kehidupan beragam yang harmonis sebagaimana kehidupan masyarakat di Madinah.

\section{Dakwah Walisongo dan Budaya Nusantara}

Sebagai bangsa yang majemuk, Indonesia memiliki beragam budaya yang berbeda antara satu daerah dengan daerah lainnya. Setiap daerah memiliki ciri khas budaya yang mencerminkan identitas mereka. ${ }^{21} \mathrm{Hal}$ itu agaknya telah menjadi sebuah sunnatullah yang telah tertuang di dalam berisan ayat-ayat al-Qur'an. Keberagaman budaya suatu bangsa tampak dari kebiasaan, adat istiadat, norma dan nilai, serta perilaku dari masyarakat itu sendiri. Seperti contoh, hampir semua suku atau daerah memiliki upacara adat, agama, rumah adat, pakaian adat, tradisi, bahkan juga norma- norma yang berbeda. Aneka warna budaya yang ada tersebut menjadi kebanggaan tersendiri bagi bangsa Indonesia. Keberagaman budaya masyarakat ini pula yang dimanfaatkan oleh para ulama untuk menyebarkan dan mengembangkan Islam di Nusantara.

Dalam menyebarkan Islam, antara ulama, masyarakat, dan budaya yang ada dalam masyarakat tersebut terdapat hubungan timbal balik. Sikap dan ketokohan seorang ulama dalam menyebarkan Islam

\footnotetext{
${ }^{20}$ Ibid.

${ }^{21}$ lihat Notowidagdo and Rohiman, Ilmu Budaya Dasar Berdasarkan AlQur`an Dan Hadis (Jakarta: Raja Grafindo Persada, 2000).
} 
akan mewarnai situasi dan kondisi yang berkembang di tengah masyarakat tersebut. Karena hal itu merupakan tugas seorang ulama yang bertujuan untuk mengarahkan dan bahkan mengubah pandangan serta wawasan keagamaan dan sosial masyarakat setempat di mana mereka berada. Sebaliknya, sepak terjang, pemikiran, serta sikap seorang ulama juga akan banyak dipengaruhi oleh kondisi yang sedang berkembang di tengah-tengah sebuah masyarakat.

Salah satu metode paling efektif yang diterapkan oleh para ulama Nusantara di awal kemunculan Islam di Indonesia adalah dengan menjadikan tradisi dan kebiasaan masyarakat setempat sebagai sarana dan media untuk menyebarkan ajaran Islam. Salah satu contohnya ialah ide cemerlang dari Sunan Kalijaga dalam memanfaatkan kepercayaan masyarakat jawa yang masih sangat kental dengan tradisi Hindhuisme dan Budhisme sebagai media untuk memperkenalkan agama Islam. Kegemaran masyarakat dalam menyaksikan pertunjukan wayang, gamelan dan beberapa pertunjukan seni lainnya mendorong Sunan Kalijaga untuk mengawinkan adat istiadat tersebut dengan ajaran Islam, atau yang sering dikenal dengan istilah Islamisasi kebudayaan. Jika pada awalnya pertunjukan wayang yang dikenal masyarakat sering bercerita tentang tokoh Hindhu atau Budha, maka Sunan Kalijaga mengubah fungsinya menjadi media untuk mempromosikan ajaran Islam, seperti memperkenalkan bahwa Tuhan itu Esa, memperkenalkan rukun-rukun Islam, memperkenalkan Nabi dan Rasul, dan lain sebagainya. ${ }^{22}$

Ajaran yang diperkenalkan walisongo lewat metode dakwah mereka adalah Islam yang bercorak sufi, sehingga dalam penerimaannya masyarakat Jawa yang tadinya banyak menganut berbagai kepercayaan lokal perlahan mengikuti ajaran Islam. Hal ini, karena Islam bercorak sufi menerima budaya lokal dan disebarkan melalui pendekatan budaya lokal. Contoh lain, adalah bahwa Islam yang dibawa walisongo ini berakulturasi dengan keyakinan lokal animisme dan dinamisme yang bersifat elastis. Keduanya menyusup dalam Islam pesantren. ${ }^{23}$ Budaya Indonesia ketika Islam datang tetap

${ }^{22}$ Suprapto, Ensiklopedi Ulama Nusantara; Choirol, "Akar Radikalisme Islam Di Indonesia"; Nasaruddin, Deradikalisasi Pemahaman Al-Qur'an Dan Hadis.

${ }^{23}$ lihat Muh Fatkhan, "Dakwah Budaya Walisongo," Aplikasia, 6, 2003, digilib.uin-suka.ac.id. 
bertahan, bahkan mewarnainya dengan corak ajaran Tauhid dalam Islam.

Dalam kaitannya dengan dakwah Nabi, Muh. Fatkhan merumuskan beberapa klasifikasi metode dakwah walisongo melalui pendekatan budaya yang berbasis metode dakwah Nabi. Pertama, metode al-hikmah. Para wali menerapkan metode ini pada orang awam. Dengan langkah yang bijaksana, secara massal masyarakat awam dihadapi dengan cara-cara yang unik bahkan sensasional dan ganjil, sehingga mengundang perhatian banyak orang. Metode ini diterapkan oleh Sunan Kalijaga dalam menciptakan tradisi sekaten, Sunan Kudus ketika ia menghias lembunya supaya masyarakat tertarik dan berkerumun di dekatnya, Sunan Ampel ketika menyusun aturanaturan Islam bagi masyarakat Jawa, Sunan Gresik ketika mengubah motif batik, lurik, dan perlengkapan kuda, dan Sunan lainnya dengan misi akulturasi budaya tertentu di daerahnya. ${ }^{24}$

Kedua, metode tadarruj atau tarbiyatul ummah, yang mengklasifikasikan masyarakat sesuai dengan tingkat pendidikannya. Para wali menempatkan dakwah sesuai dengan kapasitas keilmuan dan maqam para audiens mereka. Materi yang menyangkut tentang fiqh diajarkan di pesantren secara umum, sedangkan materi yang menyangkut ilmu kalam dan tauhid diajarkan secara khusus. Berbeda dengan hal tersebut, pengajaran tauhid kepada orang awam ditempuh melalui cerita-cerita wayang, hingga dikenal beberapa tokoh pewayangan seperti Dewa Ruci dan Kalima Sada. Dalam maqam selanjutnya, diajarkan pula ilmu tasawuf, yang oleh Sunan Bonang dilakukan melalui media wirid berupa pengajaran rahasia dan eksklusif. Ketiga, metode pembentukan dan penanaman kader serta penyebaran juru dakwah ke berbagai daerah, seperti yang dilakukan oleh Sunan Kalijaga ketika mengkader Kiai Gede Adipati Pandanarang. ${ }^{25}$

Peran walisongo sebagai penyebar sentral agama Islam di Indonesia khususnya di Jawa, menurut Clifford Geertz dapat diistilahkan sebagai Cultural-broaker. Dalam konteks tersebut, Dewi Evi Anita menyebut, bahwa komunitas masyarakat Muslim Jawa sebagai pendukung budaya telah menciptakan budayanya yang berciri

\footnotetext{
${ }^{24}$ Ibid.

${ }^{25}$ Ibid.
} 
masa peralihan, yaitu perpaduan antara unsur budaya Islami dan unsur budaya pra-Islam. ${ }^{26}$ Apa yang dilakukan oleh walisongo dalam menyebarkan Islam di Indonesia khususnya di tanah Jawa yakni dengan mendialogkan antara agama dan budaya adalah bentuk refleksi dari model harmonisasi yang dipraktikkan oleh Rasulullah Muhammad melalui isyarat yang diberikan al-Qur'an. Hal ini merupakan bentuk kepandaian walisongo dalam memanfaatkan budaya sebagai media dalam meyampaikan ajaran Islam sehingga tidak heran dalam waktu singkat Islam mampu menjadi agama dengan jumlah pemeluk mayoritas.

\section{Islam Nusantara: Wacana Tandingan Radikalisme Islam}

\section{Genealogi Islam Nusantara}

Mashlahat merupakan tujuan yang terdapat di balik ketetapan syariat. Hal ini sama halnya dengan hubungan antara lafadz dan makna. Dalam teori semantic, lafadz dan makna ibarat jasad dan ruh yang satu sama lain tidak dapat dipisahkan (Qurasih, 2015:76), begitu halnya antara syariat dan maqashid al-syariah. Para ulama merumuskan bahwa yang dimaksud dengan kemashlahatan di sini adalah apa yang disebut dengan maqashid al- syariah. Maqashid al-syariah terbagi kedalam rumusan lima prinsip pokok (al-kulliyat al-khamsah) yaitu hifdz al-din, hifdz al-nafs, hifdz al-aql, hifdz al-mal, hifdz al-nasl. ${ }^{27}$ Oleh karena itu, dalam upaya menemukan mashlahat yang dalam hal ini berupa maqashid al-syariah terdapat beberapa langkah yang harus ditempuh dan penting diperhatikan. Afifuddin Muhajir mengemukakan ada dua hal yang perlu diperhatikan dalam menemukan maqashid alsyariah:

a. Perhatian yang tertuju pada maqashid al-syariah dalam melakukan pembacaan intensif (istiqra') terhadap nushush akan melahirkan hukum yang tidak selalu tekstual tetapi juga kontekstual.

b. Dalam memecahkan persoalan yang tidak memiliki nash qath' $i$

${ }^{26}$ lihat Dewi Evi Anita, "Walisongo: Mengislamkan Tanah Jawa Suatu Kajian Pustaka," Wahana Akademika, 1, 2014, journal.walisongo.ac.id.

27 lihat Abdullah Saeed, Paradigma Prinsip Dan Metode Penafsiran Kontekstualis Atas al Qur'an, trans. Lien Iffah Naf'atu Fina and Ari Henri (Yogyakarta: Baitul Hikmah Press, 2017); Shihab Quraisy, Kaidah Tafsir (Tangerang: Lentera Hati, 2015). 
maka perlu menggunakan rujukan yang berlandaskan pada dalil-dalil sekunder (selain al-Qur'an dan Sunnah). Lahirnya dalil-dalil sekunder merupakan konsekuensi logis dari posisi mashlahat sebagai tujuan syariat. Dalil-dalil sekunder itu berupa ijma', qiyas, istihsan, sadd al-dzari'ah, 'urf, dan mashlahah mursalah. $^{28}$

Dalam masalah 'urf misalnya yang merupakan dalil yang banyak digunakan walisongo dalam mengakulturasi Islam dan budaya di Indonesia. Dalam makna literalnya, 'urf berarti tradisi atau adat istiadat yang dialami dan oleh manusia baik personal maupun komunal. 'Urf suatu masyarakat harus diperhatikan dan dipertimbangkan di dalam menetapkan hukum sepanjang tidak bertentangan dengan prinsip-prinsip syariat sebab mengabaikan 'urf shohih. ${ }^{29}$

Adapun sebagian ulama menjadikan posisi 'urf sebagai hujjah syar'iyah didasarkan pada al-Qur'an dan hadis yang diriwayatkan Ibn Mas'ud. Dalam kitab al-Mabsuth, Imam al-Sarakhsi berpendapat bahwa apa yang ditetapkan oleh 'urf sama kedudukannya dengan apa yang ditetapkan di dalam nash. Adanya kaidah 'urf ini semakin meneguhkan bahwa Islam bukanlah agama yang memarjinalkan konsep kebudayaan, melainkan Islam tetap menjaga eksistensinya bahkan mengadopsinya dalam upaya memperoleh dan mentransformasikan mashlahat. Selain nushush al-syariah dan maqashid al-syariah, Islam juga memiliki apa yang disebut dengan mabadi' al-syariat yakni wasathiyah. Prinsip wasathiyah atau moderasi ini salah satu makna lainnya adalah waqi'iyah (realistis). Konsep ini berasal dari al-Qur'an secara langsung dalam Q.S alBaqarah: 143.

Jika moderasi ini dikaitkan dengan praktik dakwah walisongo, dapat diketahui bahwa mereka melanggengkan praktik waqi'iyah ini dalam upayanya menyebarkan Islam di tanah air. Sunan Kalijaga dan Sunan Kudus misalnya. Sunan Kalijaga begitu toleran dengan budaya lokal. Sikap toleransi inilah yang menyebabkan beliau yakin bahwa perang ideologi dapat terjadi apabila ia memaksakan ideologinya kepada masyarakat. Dalam hal ini, beliau telah mengamalkan kaidah

${ }^{28}$ lihat Afifuddin Muhajir, "Islam Nusantara Untuk Peradaban Islam Dan Dunia," in Islam Nusantara: Dari Ushul Fiqh Hingga Paham Kebangsaan, by Munawir Aziz and ahmad Sahal (Bandung: Mizan Pustaka, 2015).

${ }^{29}$ lihat Abdul Wahab Kholaf, Ilmu Ushul Fiqh (Kairo: Dar al-Turats, 2009). 
fiqh realitas: 1) menolak kerusakan didahulukan dari pada mendatangkan kemashlahatan"; 2) turun kepada realitas yang lebih rendah tatkala mustahil mencapai idealitas yang lebih tinggi; dan 3) beradaptasilah dengan mereka selama kamu berada di kediaman mereka dan hormatilah mereka selam kamu berada di kampung mereka. Dengan sikap toleransi tersebut, terlihat bahwa ajaran Islam yang diperkenalkan oleh sunan Kalijaga terkesan sinkretis karena bercampur dengan budaya sebagai medianya. Seni ukir, wayang, gamelan, baju taqwa, perayaan sekaten di Keraton, grebeg, maulud, sholawatan dan lainnya merupakan bentuk penghargaan beliau dalam menilai sebuah budaya. Metode dakwah yang efektif inilah yang mampu menarik simpati para pemimpin tataran Jawa waktu itu.

Begitupula dengan apa yang dilakukan oleh sunan Kudus yang mampu mengawinkan antara simbol-simbol kebudayaan yang pada masa itu sangat erat kaitannya dengan pengaruh agama Hindu dan Buddha. Sebagai buktinya sampai sekarang arsitektur masjid Kudus, baik itu menaranya, gerbangnya, dan tempat wudhunya, melambangkan delapan jalan Budha sehingga terkesan sangat berbeda dengan arsitektur masjid pada umumnya. Adapun wujud kompromi beliau dengan adat Hindu dapat dilihat dari sikap warga Muslim Kudus yang sampai sekarang enggan menyembelih sapi karena mereka khawatir hal itu akan merusak toleransi antara muslim dan hindu.

Akan tetapi, satu hal yang harus digarisbawahi dalam melihat dakwah walisongo, adalah kembali lagi melihat dimensi yang ada dalam ajaran Islam sendiri. Bahwa bagian dari ajaran yang bisa dikombinasikan dengan budaya adalah dimensi yang bersifat historis dan temporal (muamalah). Adapun dalam dimensi normatif (ibadah) maka tidak selah untuk memasukkan unsur budaya di dalamnya. Semisal dalam kiadah fiqh Ibadah dikatakan "Allah tidak disembah kecuali dengan apa yang telah disyariatkan" atau "hukum asli dari ibadah adalah haram sampai adanya dalil yang menunjukkan kebolehannya", sedangkan dalam kaidah fiqh mualamah dikatakan" mu'amlah itu longgar sampai diketahui dalil yang melarang" atau "hukum asli dari mu'amalah itu adalah boleh sampai adanya dalil yang menunjukkan keharamannya". ${ }^{30}$

${ }^{30}$ Ibid. 
Deskripsi penjelasan sebelumnya dikemukakan untuk menunjukkan manhaj Islam Nusantara sebagaimana yang telah dibangun dan diterapkan oleh walisongo serta diikuti oleh ulama Nusantara hingga saat ini. Jadi dapat disimpulkan bahwa apa yang dimaksud dengan Islam Nusantara adalah paham dan praktik keislaman di bumi Nusantara sebagai hasil dialektika antara teks syariat dan realitas budaya Nusantara. ${ }^{31}$ Sehingga apabila ini dikaitkan dengan penjelasan sebelumnya tentang dialektika budaya dan syariat di masa Rasulullah, didapati sebuah kesamaan realitas dimana Islam menggunakan budaya sebagai sarana dalam mentransformasikan ajaran-ajaran universalnya ke dalam masyarakat.

Adapun upaya pelanggengan konsep Islam Nusantara oleh ulama Nusantara pasca wali songo adalah bentuk pengamalan kaidah al-muhafadzah 'ala al-qadim al-sholih. Adapun dalam penerapan kaidah selanjutnya, al-akhdzu bi al-jadid al-aslah, modernisasi adalah sebuah realitas yang tidak bisa ditolak sebagai implikasi dari adanya globalisasi. Dalam hal ini, Islam diharapkan mampu mengakomodasi perkembangan teknologi tersebut semisal menggunakan media sosial sebagai sarana baru dalam memperkenalkan Islam Nusantara sebagai upaya untuk mengekspor manhaj Islam Nusantara ke seluruh penjuru dunia.

2. Islam Nusantara Sebagai Solusi Problem Radikalisme di Era Milenial

Seperti yang telah dijelaskan dalam sub bab sebelumnya tentang radikalisme, dari kelima ciri yang dikemukakan John L.Esposito dapat dipahami bahwasanya kelompok radikal menggunakan pola gerakan yang bertahap. Pertama, interaksi yang terjadi antara umat Muslim dengan budaya Barat menghasilkan sebuah ideologi bernegara (Pancasila) yang mereka anggap tidak pantas dijadikan pegangan, karena menurut mereka pemerintahan harus berdasarkan pada syariat Islam yang murni, bukan yang lainnya. Mereka kemudian menjustifikasi kelompok lain yang tidak sepaham dengan ungkapan "kafir". Justifikasi yang ditampilkan kelompok radikal ini lahir karena karakter dzhohiriyah mereka yang hanya melihat suatu problematika berdasarkan "kulitnya", seperti politisasi makna sebagai legitimasi ideologis yang dilakukan mereka terhadap ayat-ayat "jihad". Sehingga,

${ }^{31}$ Muhajir, "Islam Nusantara Untuk Peradaban Islam Dan Dunia.” 
kelompok yang memiliki kecenderungan puritan ini tidak akan menerima apa yang disebut dengan akulturasi budaya dalam agama dan tidak akan memahami hubungan antara teks dan konteks. ${ }^{32}$ Implikasi selanjutnya, mereka mengambil sikap oposisi demi klaim kebenaran dan simpatisan. Setelah massa dengan jumlah besar terkumpul, mereka mendengungkan seruan jihad untuk menggulingkan pemerintahan yang ada demi mewujudkan khilafah Islamiyah sebagaimana yang mereka pahami dan cita-citakan.

Dalam kasus ini, perlu adanya klarifikasi bahwa Pancasila yang termasuk ke dalam produk Islam Nusantara bukanlah ideologi sekuler sebagaimana yang mereka klaim. Pancasila dalam dimensi substansialnya mencerminkan nilai-nilai universal Islam. Jika ditelisik lebih lanjut, tujuan pendirian negara dalam Islam adalah untuk mewujudkan keadilan dan kemakmuran yang berketuhanan Yang Maha Esa, sehingga memiliki dimensi duniawi dan ukhrawi. ${ }^{33}$ Dimensi substansial dari penyelenggaraan negara juga diungkapkan oleh Imam Mawardi yang mengatakan "Seorang pemimpin atau dalam hal ini sebuah konsep kepemimpinan diposisikan sebagai pengganti tugas kenabian dalam menjaga eksistensi agama (Islam) serta mengatur kebijakan di dunia". ${ }^{34}$ Lahirnya Pancasila tidak bisa dilepaskan dari adanya interaksi agama (Islam) dan budaya di Indonesia yang kemudian dikonsepsi menjadi lima prinsip pokok dan diterima serta disepakati menjadi ideologi bagi negara Indonesia. Sila pertama pacasila merupakan bentuk representasi dari nilai Tauhid dalam ajaran Islam. Sedangkan sila-sila selanjutnya merupakan bentuk representasi nilai-nilai universal Islam. Dengan mempertimbangkan keragaman Indonesia, pemilihan Pancasila sebagai ideologi negara adalah keputusan yang paling tepat.

Islam Nusantara yang mabādi' al-syariat-nya adalah sikap wasatiyah dalam hal ini mampu menjadi soft solution bagi maraknya problematika radikalisme dewasa ini. Islam Nusantara mampu mempertahankan eksistensinya dan menampakkan wajahnya yang teduh, toleran serta penuh kedamaian. Fenomena era milenial yang merebak sampai Indonesia yang ditimbulkan oleh globalisasi berupa

${ }^{32}$ Saeed, Paradigma Prinsip Dan Metode Penafsiran Kontekstualis Atas al Qur'an; Quraisy, Kaidah Tafsir.

${ }^{33}$ Muhajir, "Islam Nusantara Untuk Peradaban Islam Dan Dunia." 34 Ibid.

Analisis: Jurnal Studi Keislaman, Volume 19, No. 1, Juni 2019 
era gawai, internet, media sosial, dan the borderless world, menyebabkan budaya masyarakat milenial sangat dekat dengan hal-hal tersebut. Menurut Severin dan Tankard, internet dapat dimanfaatkan sebagai bahan pengajaran, hiburan, dan komunikasi. ${ }^{35}$ Oleh karena itu, jika metode dakwah yang memperhatikan kebudayaan ala Nabi dan walisongo diterapkan di budaya milenial ini, maka dakwah harus diintegrasikan dengan beberapa elemen di atas. Artinya, Islam Nusantara sebagai wacana tandingan dan solusi atas problem radikalisme Islam harus marak disebarkan melalui media, baik berupa internet, gawai, ataupun media sosial. Hal ini sebanding dengan arus radikalisme Islam yang disebutkan gencar merebak karena adanya pengaruh media. Adapun secara praksis, ide ini dapat diimplementasikan dengan penguatan ide Islam Nusantara dalam literasi digital dan pembuatan akun-akun Islam ramah di media sosial.

\section{E. Simpulan}

Penolakan kebudayaan oleh sementara kelompok Muslim yang radikal dengan alasan memurnikan ajaran Islam perlu diteliti kembali, karena berdasarkan fakta historis Rasulullah telah mengakomodasi kebudayaan Arab tatkala menyampaikan dakwahnya. Islam di Indonesia, seperti halnya dakwah Nabi telah banyak berinteraksi dengan kebudayaan. Hal ini tampak dalam metode dakwah yang dipraktikkan walisongo ketika menyebarkan Islam di Nusantara, khususnya di Jawa. Islam yang tampak pada masa itu berupa Islam ramah yang berdialektika dengan budaya, adat, dan tradisi lokal, sehingga dapat mengundang simpati masyarakat. Dari sini, terdapat benang merah bahwa dakwah Nabi dan dakwah ulama Nusantara, yaitu walisongo, merupakan dakwah yang ramah karena memperhatikan eksistensi budaya setempat. Islam Nusantara merupakan ekspresi keberagamaan Islam yang sesuai dengan budaya lokal Nusantara, karena di dalamnya terdapat dialektika antara teks keagamaan dengan budaya dan tradisi lokal Nusantara. Wacana Islam Nusantara perlu dikembangkan menyesuaikan dengan budaya dan realitas zaman. Jika ditarik sebuah relevansi antara dakwah Nabi dan walisongo yang

${ }^{35}$ lihat Heru Dwi Wahana, "Pengaruh Nilai-Nilai Budaya Generasi Milenial Dan Budaya Sekolah Terhadap Ketahanan Individu (Studi Di SMA Negeri 39, Cijantung, Jakarta)," Jurnal Ketahanan Nasional, 21, 1 (2015), www.researchgate.net. 
memperhatikan budaya, maka dapat disimpulkan bahwa gagasan Islam Nusantara pada era milenial perlu disebarluaskan sesuai dengan budaya yang ada saat ini. Oleh karena itu, juga dalam kaitannya dengan kenyataan bahwa kelompok Islam radikal menyebarkan ideologinya melalui perantara media, gagasan Islam Nusantara yang mengakomodasi budaya lokal pun perlu disebarluaskan melalui perantara media, baik berupa gawai, internet, media massa, atau media sosial. [.]

\section{Daftar Rujukan}

Abdullah, Anzar. "Gerakan Radikalisme Dalam Islam: Perspektif Historis." Addin, 1, 10 (2016). www.researchgate.net.

Ahmad Baso. Islam Nusantara Ijtihad Jenius Dan Ijma' Ulama Indonesia. Tangerang Selatan: Pustaka Afid, 2015.

Ali Sodiqin. Antropologi Al-Qur'an: Model Dialektika Wahyu Dan Budaya. Yogyakarta: Ar-Ruzz Media, 2012.

. "Sejarah Harmonisasi Islam Dan Kebudayaan Mazhabuna." Digilib Uin Suka.Ac.Id, 1, 7 (2013).

Bagir, Haidar. Islam Tuhan Islam Manusia Agama Dan Spiritualitas Di Zaman Kacau. Bandung: Mizan, 2007.

Choirol, Ummah, Sun. "Akar Radikalisme Islam Di Indonesia." Humanika, no. 2 (2012). media.neliti.com.

Dewi Evi Anita. "Walisongo: Mengislamkan Tanah Jawa Suatu Kajian Pustaka." Wahana Akademika, 1, 2014. journal.walisongo.ac.id.

Esposito, John L. Islam And Secularism In The Middle East. London: C. Hurst and Co, 2002.

Fatkhan, Muh. "Dakwah Budaya Walisongo." Aplikasia, 6, 2003. digilib.uin-suka.ac.id.

Irwan Masduki. Berislam Secara Toleran Teologi Kerukunan Umat Beragama. Bandung: Mizan Pustaka, 2011.

Kholaf, Abdul Wahab. Ilmu Ushul Fiqh. Kairo: Dar al-Turats, 2009. 
Manna', Al-Qathan. Mabahits Fi Ulum Al-Qur'an. Beirut: Dar alKutub al-Ilmiyah, 1973.

Muhajir, Afifuddin. "Islam Nusantara Untuk Peradaban Islam Dan Dunia." In Islam Nusantara: Dari Ushul Fiqh Hingga Paham Kebangsaan, by Munawir Aziz and ahmad Sahal. Bandung: Mizan Pustaka, 2015.

Muhammad Hasan Tholhah. Islam Dan Radikalisme Agamadiakses 20 Maret 2018. 1p3.um.ac.id, 2013.

Mujamil, Qomar. "Islam Nusantara: Sebuah Alternatif Model Pemikiran, Pemahaman, Dan Pengamalan Islam”. Vol. 2. 17. El Harakah, 2015.

Nasaruddin, Umar. Deradikalisasi Pemahaman Al-Qur'an Dan Hadis. Jakarta: Quanta, 2009.

Notowidagdo, and Rohiman. Ilmu Budaya Dasar Berdasarkan AlQur`an Dan Hadis. Jakarta: Raja Grafindo Persada, 2000.

Quraisy, Shihab. Kaidah Tafsir. Tangerang: Lentera Hati, 2015.

Saeed, Abdullah. Paradigma Prinsip Dan Metode Penafsiran Kontekstualis Atas al Qur'an. Translated by Lien Iffah Naf'atu Fina and Ari Henri. Yogyakarta: Baitul Hikmah Press, 2017.

Suprapto, Bibit. Ensiklopedi Ulama Nusantara. Bogor: Gelegar Media Indonesia, 2009.

Wahana, Heru Dwi. "Pengaruh Nilai-Nilai Budaya Generasi Milenial Dan Budaya Sekolah Terhadap Ketahanan Individu (Studi Di SMA Negeri 39, Cijantung, Jakarta)." Jurnal Ketahanan Nasional, 21, 1 (2015). www.researchgate.net.

Yusuf, and dkk. Islam Dan Budaya Lokal. Yogyakarta: Pokja Akademik UIN Sunan Kalijaga, 2005. 